\title{
Hepatocyte Proliferation and Gene Expression Induced by Triiodothyronine In Vivo and In Vitro
}

\author{
Antonio Francavilla, ${ }^{1}$ Brian I. CarR, ${ }^{2}$ Alessandro Azzarone, ${ }^{1}$ Lorenzo Polimeno, ${ }^{1} \mathrm{ZiQIU} \mathrm{WANG}^{2}$ \\ David H. VAN Thiel, ${ }^{2}$ Vladimir Subbotin, ${ }^{2}$ John G. Prelich ${ }^{2}$ AND Thomas E. StarzL ${ }^{2}$ \\ ${ }^{1}$ Department of Gastroenterology, University of Bari, 70100 Bari, Italy; and ${ }^{2}$ Department of Surgery, University of \\ Pittsburgh Medical Center, Pittsburgh, Pennsylvania 15240
}

Subcutaneous injections of hormone triiodothyronine in rats resulted in peak blood levels at $24 \mathrm{hr}$ with return to baseline by $96 \mathrm{hr}$. The injections stimulated a liver regeneration response that resembled in timing and in magnitude of DNA synthesis (peak, $24 \mathrm{hr}$ ) that induced by $40 \%$ hepatic resection. The principal proliferation was of hepatocytes. Although there were some temporal differences from the gene expression of transforming growth factor- $\alpha$, transforming growth factor- $\beta$, and $c$-Ha-ras that are known to follow partial hepatectomy, the overall profile of these changes was similar to those after partial resection. The effect was liver specific and could be reproduced three times with no diminution in response in the same animal with injections at 10-day intervals. No response was detected in kidney or intestine. This effect in intact animals contrasted with the minimal ability of triiodothyronine to stimulate hepatocytes in culture. However, when the culture medium was enriched with epidermal growth factor, there was a dose-related response to triiodothyronine. The totality of these experiments provides a preliminary basis for the creation with pharmacological techniques of an in vivo hyperplastic hepatic condition permissive of transfection of new genes, as an alternative to partial hepatectomy. Although triiodothyronine was the test agent used, other hepatic growth factors singly or in combination could be candidates for this purpose. (HePATOLOGY 1994;20:1237-1241.)

The influence of $T_{3}$ on liver growth control has been demonstrated in rats by reduction in the normal hepatic regeneration response after thyroidectomy (1) and,

Received January 12, 1994; accepted May 2, 1994.

Other abbreviations used in the text: AFP, $\alpha$-fetoprotein; EDTA, ethylenediaminetetraacetate; EGF, epidermal growth factor; HEPES, N-2-hydroxyethylpiperazine-N-2-ethanesulfonic acid; $\mathrm{T}_{3}$, triiodothyronine; TGF, transforming growth factor.

This study was supported by research grants from the Veterans Administration, project grant DK 29962 from the National Institutes of Health and by Consiglio Nazionale delle Ricerche, ACRO Program, Grant number 93-02187. PF39.

Address reprint requests to: Antonio Francavilla, M.D., VA Medical Center, University Drive C, Building 6, Room 110, Pittsburgh, PA 15240.

Copyright (C) 1994 by the American Association for the Study of Liver Diseases.

$0270-9139 / 94 \$ 3.00+0 \quad 31 / 1 / 58872$ alternatively, by a proliferative response seen after subcutaneous $\mathrm{T}_{3}$ injections in unaltered animals $(2,3) . \mathrm{T}_{3}$ also has modest hepatotrophic effects $(4)$ that are identified in the Eck fistula screen model by the stimulation of proliferation and the prevention of hepatocyte atrophy (5). In this study, we further characterized the rat liver's response to $\mathrm{T}_{3}$ including the mRNA to $\mathrm{T}_{3}$ expression of the growth-associated genes TGF- $\alpha$, TGF- $\beta$ and cHa-ras. Our immediate objective was to determine whether the changes in gene expression were comparable to those known to occur after partial hepatectomy $(6,7)$. For the transfection of new genes, a process that is known to be facilitated and prolonged under conditions of cellular proliferation (8), $\mathrm{T}_{3}$ may be an acceptable substitute for partial hepatectomy.

\section{MATERIALS AND METHODS}

Animals. Male Fischer F344 rats weighing between 180 and $200 \mathrm{gm}$ were obtained from Hilltop Lab Animals, Inc. (Scottsdale, PA). The animals were housed in a temperature- and light-controlled room $\left(21^{\circ}\right.$ to $22^{\circ} \mathrm{C}$, light from $6 \mathrm{AM}$ to $\left.6 \mathrm{PM}\right)$ and received food and water ad libitum.

Materials. Type I collagenase (140 to $170 \mathrm{units} / \mathrm{mg}$ ) was purchased from Worthington Diagnostic Systems (Freehold, NJ). Other materials and sources were formalin (Baxter Health Care Corp., McGaw Park, IL), Eagle's minimal essential medium and fetal calf serum (GIBCO Laboratories, Grand Island, NY), insulin, HEPES, pyruvic acid and $\mathrm{T}_{3}$ (Sigma Chemical Co., St. Louis, MO), EGF (Collaborative Research, Inc., Bedford, MA), [methyl ${ }^{3} \mathrm{H}$ ] thymidine (50 to 80 $\mathrm{Ci} / \mathrm{mmol}$ ) (Du Pont-New England Nuclear, Boston, MA), 35-mm tissue culture dishes (Corning, Inc., Corning, NY), gentamicin (Elins-Sinn, Inc., Cherry Hill, NJ), aqueous counting solution (Amersham, Arlington Heights, IL) and monoclonal rabbit Elite anti-human AFP antibodies (Dako Corp., Carpinteria, CA).

Probes Used. cDNA fragments of human c-Ha-ras (cDNA Probe, Oncogene Science, Inc., Cambridge, MA), human TGF- $\beta 1$ (9) (gift of Dr. A. Derynk, Genentech, Inc., San Francisco, CA) and rat TGF- $\alpha$ (10) (gift of Dr. David C. Lee, University of North Carolina, Chapel Hill, NC) were labeled with [ $\left.{ }^{32} \mathrm{P}\right] \mathrm{dCTP}$ by means of random priming (Random Primer Labeling System; BRL, Indianapolis, IN). An oligo for 28S cDNA (Oligo Probe; Oncor, Inc. Gaithersburg, MD) was 
TABLE 1. Effects of different concentrations of $T_{3}$ on hepatocyte proliferation in medium enriched with EGF and TGF- $\beta$

\begin{tabular}{|c|c|}
\hline$\underset{(\mathrm{ng} / \mathrm{ml})}{\text { Medium additions }}$ & $\begin{array}{c}{\left[{ }^{3} \mathrm{H}\right] \text { Thymidine incorporation }} \\
\left(\mathrm{cpm} \times 10^{-3} / \mu \mathrm{g} \text { proteins }\right)\end{array}$ \\
\hline 0 & $102 \pm 61^{a}$ \\
\hline $\mathrm{T}_{3}(1 \mathrm{ng})$ & $124 \pm 70$ \\
\hline$E G F+T_{3}(0.01 n g)$ & $1,109 \pm 98$ \\
\hline $\mathrm{EGF}+\mathrm{T}_{3}(0.1 \mathrm{ng})$ & $1,480 \pm 129^{b}$ \\
\hline $\mathrm{EGF}+\mathrm{T}_{3}(1.0 \mathrm{ng})$ & $1,920 \pm 131^{b}$ \\
\hline $\mathrm{EGF}+\mathrm{T}_{3}(10 \mathrm{ng})$ & $1,811 \pm 191^{b}$ \\
\hline $\mathrm{EGF}+\mathrm{T}_{3}(1 \mathrm{ng})+\mathrm{TGF}-\beta(1 \mathrm{ng})$ & $304 \pm 148$ \\
\hline
\end{tabular}

${ }^{a}$ Data expressed as mean \pm S.D.

${ }^{b}$ Significantly different from the value obtained with EGF (10 $\mathrm{ng} / \mathrm{ml}$ ) alone in the culture medium: $\mathrm{p}<0.01$.

labeled with $\left[{ }^{32} \mathrm{P}\right] \mathrm{dCTP}$ by use of $\mathrm{T} 4$ kinase (end labeling system; BRL).

In Vivo Experiments. Injections $(200 \mu \mathrm{g} / 100 \mathrm{gm}$ rat body wt) of $\mathrm{T}_{3}$ were made subcutaneously on the backs of the animals in $0.1 \mathrm{ml}$ of $0.01 \mathrm{~N} \mathrm{NaOH}-0.9 \% \mathrm{NaCl}$ solution. Control rats were given similar injections of vehicle solution.

DNA synthesis was determined in the livers, kidneys and small intestines of rats injected intraperitoneally with $50 \mu \mathrm{Ci}$ $\left[{ }^{3} \mathrm{H}\right]$ thymidine/200 gm body wt $1 \mathrm{hr}$ before being killed; the incorporation of $\left[{ }^{3} \mathrm{H}\right]$ thymidine was then determined as described previously $(11,12)$.

Proteins were determined by the method of Lowry et al. (13). Serum levels of $\mathrm{T}_{3}$ were determined by means of RIA (Ciba Corning MAGIC T3 commercial kit; Ciba Corning Diagnostic Ltd., Halstead, Essex, UK). This procedure can measure $\mathrm{T}_{3}$ concentrations to $8.0 \mathrm{ng} / \mathrm{ml}$, with a minimum detectable concentration of less than $0.1 \mathrm{ng} / \mathrm{ml}$. The coefficient of variation of replicative sample assayed in our laboratory was $6.53 \%$.

Tissue specimens from rat livers were fixed in $10 \%$ buffered formalin and embedded in paraffin; 4- $\mu \mathrm{m}$ sections were prepared and stained with hematoxylin and eosin. Monoclonal rabbit Elite anti-human AFP antibodies were used to examine AFP-positive cells. AFP immunostaining was performed as described by Palmer et al. and Strenberger $(14,15)$, with the peroxidase avidin-biotin complex method (ABC; Vector Laboratories, Burlingame, $\mathrm{CA}$ ) and trypsin digestion control. The primary antibody dilution was $1: 250$. As a positive control, anti-human AFP antibodies were tested in fetal rat liver sections.

In Vitro Experiments. Hepatocytes from the livers of unaltered 7 -wk-old male rats (180 to $200 \mathrm{gm}$ ) were isolated by means of a modification (16) of the in situ two-step collagenase perfusion technique $(17,18)$. Hepatocytes were dispersed and washed twice with cold $\mathrm{Ca}^{++}$-free perfusion buffer and resuspended in serum-free Williams $E$ medium supplemented with EGF on fibronectin-coated dishes. Viability was determined by means of trypan blue exclusion, and only preparations with viability greater than $90 \%$ at the outset were used. Cell number was determined with a hemocytometer. The cells were plated at a cell density of $3 \times 10^{5} / 35 \mathrm{~mm}$ in Corning tissue-culture dishes containing $1.5 \mathrm{ml}$ medium and maintained at $37^{\circ} \mathrm{C}$ in a $5 \% \mathrm{CO}_{2}$ atmosphere. After a 3-hr attachment period, the medium was aspirated, and $1.5 \mathrm{ml}$ of Williams E medium with or without EGF, $10 \mathrm{ng} / \mathrm{ml}$, was added. $\mathrm{T}_{3}$ and TGF- $\beta$, when used, were at the concentrations reported in Table 1.

To determine in vitro DNA synthesis, we added $3 \mu \mathrm{Ci}$ $\left[{ }^{3} \mathrm{H}\right]$ thymidine to each well and maintained it from 48 to $72 \mathrm{hr}$
TABLE 2. DNA synthesis in kidney and small intestine from control (vehicle) and $T_{3}$-treated rats

\begin{tabular}{|c|c|c|c|}
\hline \multirow[b]{3}{*}{ Organ } & \multicolumn{3}{|c|}{$\begin{array}{l}\left.{ }^{3} \mathrm{H}\right] \text { thymidine incorporation } \\
\left(\mathrm{cpm} / \mathrm{mg} \text { DNA } \times 10^{-3}\right)\end{array}$} \\
\hline & \multirow[b]{2}{*}{ Vehicle (24 hr) } & \multicolumn{2}{|c|}{ T3 } \\
\hline & & $24 \mathrm{hr}$ & $48 \mathrm{hr}$ \\
\hline Kidney & $2.6 \pm 0.4^{a}$ & $2.5 \pm 0.4$ & $2.4 \pm 0.3$ \\
\hline Small intestine & $13.2 \pm 2.2$ & $15.7 \pm 0.8$ & $13.7 \pm 2.5$ \\
\hline
\end{tabular}

${ }^{a}$ Data expressed as mean \pm S.D.

of the culture period. When the cells were harvested, DNA content was determined by use of the microfluorometric method of Setaro and Morley (19), and DNA synthesis was measured as we have previously reported (16).

Gene Expression Studies. Total cellular RNA from the rat livers was extracted by use of RNAzol (Biotecx, Houston, TX). Total RNA $(20 \mu \mathrm{g})$ was subjected to electrophoresis in a $1 \%$ agarose gel in $10 \mathrm{mmol} / \mathrm{L} \mathrm{Na}_{3} \mathrm{PO}_{4}$ with constant recirculation. The fractionated RNA was transferred to a Zitabind nylon membrane (Whatman, Maidstone, UK) overnight in $20 \times$ standard saline citrate. After transfer, the blot was fixed with UV light (short wave, $254 \mathrm{~nm}$ ). cDNA probes were labeled with ${ }^{32} \mathrm{P}$ with a random-primed labeling kit. Prehybridization was performed at $70^{\circ} \mathrm{C}$ from $30 \mathrm{~min}$ to $3 \mathrm{hr}$ with Church buffer ( $1 \%$ BSA, $7 \%$ SDS, $0.5 \mathrm{~mol} / \mathrm{L}$ sodium phosphate, $1 \mathrm{mmol} / \mathrm{L}$ EDTA). For hybridization, ${ }^{32} \mathrm{P}$-labeled denatured probes in Church buffer were added at $70^{\circ} \mathrm{C}$ for hybridization (20). After hybridization, the membranes were washed twice in buffer A (1\% BSA, 5\% SDS, $40 \mathrm{mmol} / \mathrm{L}$ sodium phosphate and $1 \mathrm{mmol} / \mathrm{L}$ EDTA) at $70^{\circ} \mathrm{C}$ for $20 \mathrm{~min}$ and then washed in buffer B (1\% $\mathrm{SDS}, 40 \mathrm{mmol} / \mathrm{L}$ sodium phosphate and $1 \mathrm{mmol} / \mathrm{L}$ EDTA) at $70^{\circ} \mathrm{C}$ for $20 \mathrm{~min}$ (four times).

The washed, air-dried membranes were subjected to autoradiography at $-70^{\circ} \mathrm{C}$. To check for equivalent transfer of RNAs from agarose gel to membrane, we stained the gel with ethidium bromide after capillary transfer: Little RNA was found to remain in any lane. Before probe hybridization, the membranes were checked under UV light; similar amounts of RNA were found to have been transferred to each lane. This was always confirmed with separate probing with cDNA for 28S RNA. The probes used were described. The products were subjected to electrophoresis on a $2 \%$ agarose gel with molecular-weight markers. The determination of TGF- $\alpha$, TGF- $\beta$, and Ha-ras was chosen because the behavior of those genes has been completely established during the course of liver regeneration after partial hepatectomy $(7,9,10)$.

Statistical Analysis. Data are reported as mean \pm S.D. The Student one-tailed $t$ test was used for statistical analysis of the data. Any $p$ value less than 0.05 was considered significant.

\section{RESULTS}

In Vivo Experiments. The serum concentration of $\mathrm{T}_{3}$ rose from control of $0.7 \pm 0.3 \mathrm{ng} / \mathrm{ml}$ to $38.9 \pm 5.3 \mathrm{ng} / \mathrm{ml}$ after $24 \mathrm{hr}$ and had returned to control values by 4 days. Repeat injections 10 and 20 days later caused 24 -hr peak levels of $28.2 \pm 6.5$ and $46.3 \pm 7.4 \mathrm{ng} / \mathrm{ml}$, respectively, with return to control by $96 \mathrm{hr}$.

A peak response in DNA synthesis and mitoses was found at $24 \mathrm{hr}$ followed by a lower second peak at $48 \mathrm{hr}$. Return to baseline required $96 \mathrm{hr}$ (Fig. 1). When a second injection of $T_{3}$ was given to the same animals 10 and 20 days after the first one, the same response was 


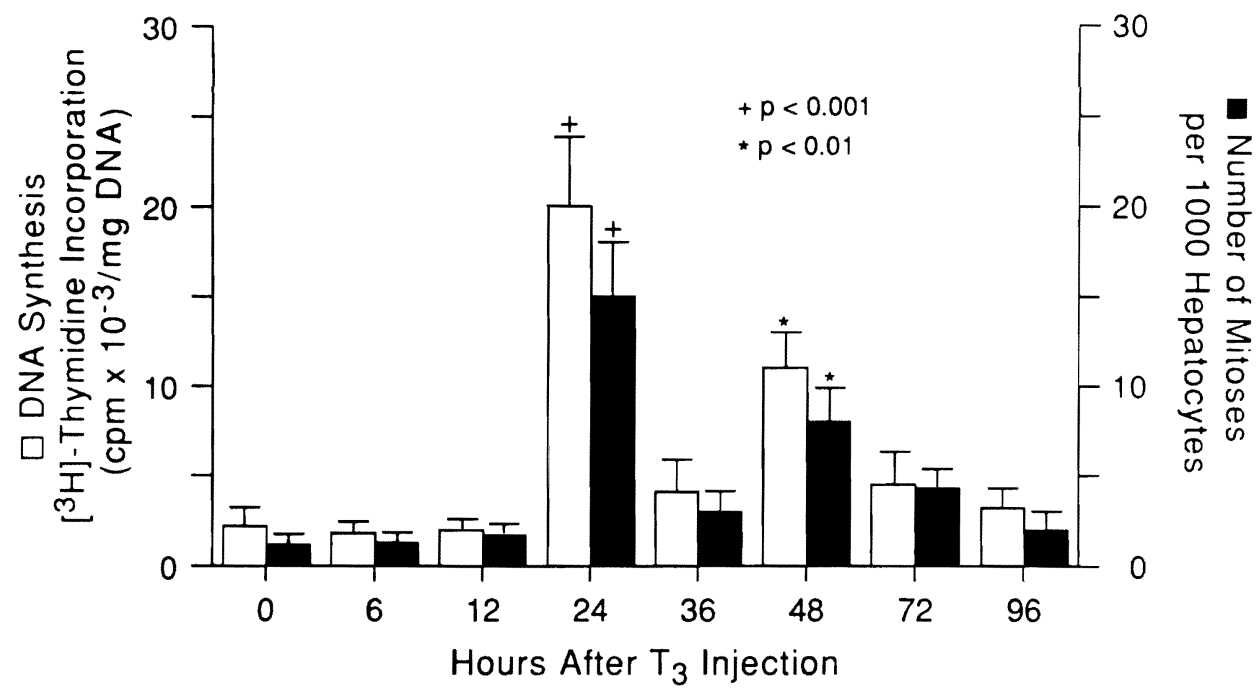

FIG. 1. Effect of a single injection of $\mathrm{T}_{3}(200 \mu \mathrm{g} / 100 \mathrm{gm}$ body wt $)$ on DNA synthesis and number of mitoses at different points after hormone injection. Significantly different from 0 time value: ${ }^{+} \mathrm{p}<0.001 ;{ }^{*} \mathrm{p}<0.01$.

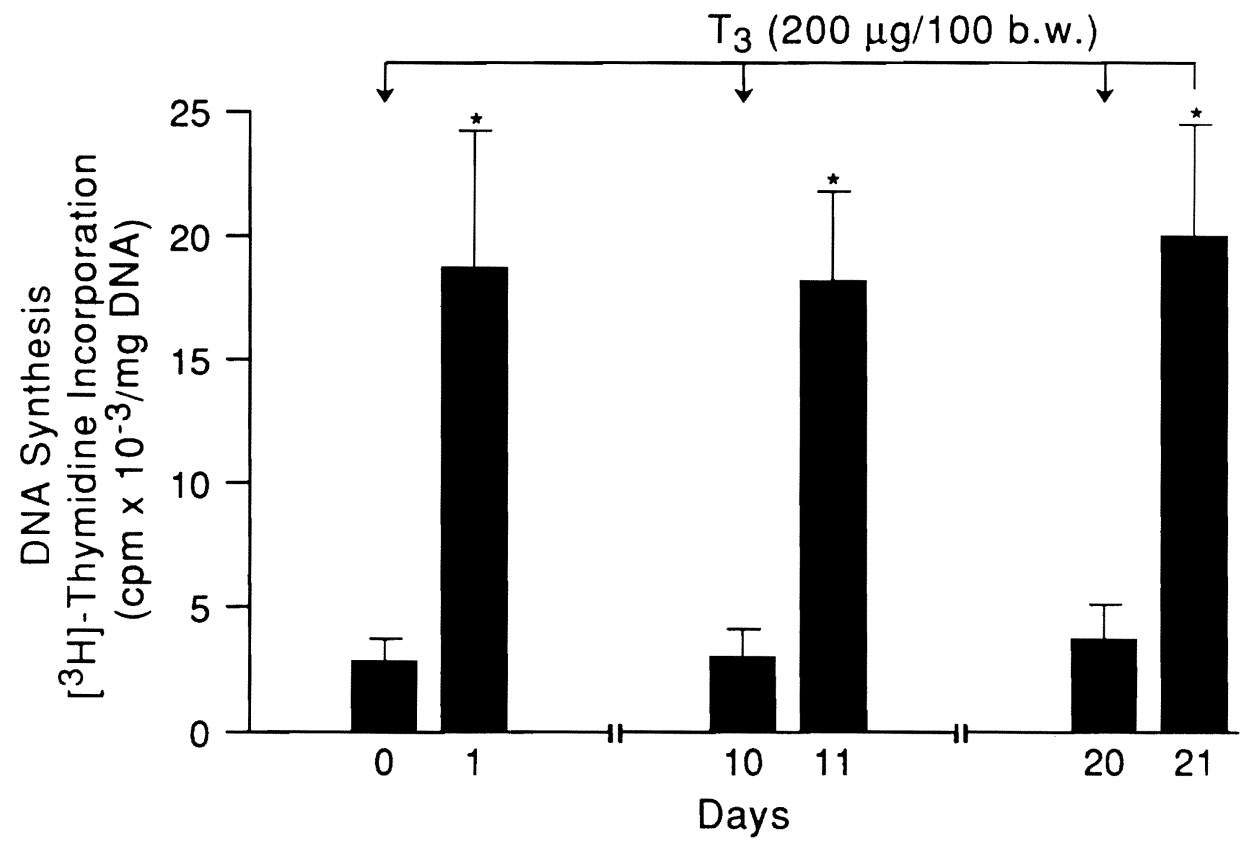

FIG. 2. Effect of repeated doses of $T_{3}$ on hepatic DNA synthesis. Significantly different from the value observed, each time, in the rats before $\mathrm{T}_{3}$ injection: ${ }^{*} \mathrm{p}<0.01$.

obtained on all three occasions (Fig. 2). On histological and immunohistochemical examination, the mitotic figures were found predominantly in the AFP-negative hepatocytes.

$\left[{ }^{3} \mathrm{H}\right]$ thymidine incorporation in the kidneys and small intestine was not affected by $\mathrm{T}_{3}$ administration (Table 2).

In Vitro Experiments. $\mathrm{T}_{3}$ alone had a minimal stimulatory effect but caused a dose-related amplification of the DNA synthesis response to the primary hepatocyte mitogen EGF (Table 1).

Gene Expression. $\mathrm{T}_{3}$ induced distinct peaks of TGF- $\alpha$ expression, the principal one at $24 \mathrm{hr}$ (Fig. 3) with a subsequent return almost to baseline. The second peak of increased expression appeared at $72 \mathrm{hr}$ after $\mathrm{T}_{3}$ injection. The expression of c-Ha-ras was increased from $24 \mathrm{hr}$ to $120 \mathrm{hr}$ (Fig. 4). The peak expression of TGF- $\beta$ was from $72 \mathrm{hr}$ to $120 \mathrm{hr}$ (Fig. 4). The mRNA of $28 \mathrm{~S}$, a nongrowth gene, was used as an internal standard in all experiments to which other RNAs could be compared (Figs. 3 and 4).

\section{DISCUSSION}

The simplicity of $\mathrm{T}_{3}$ injection for induction of hepatic proliferation in vivo suggests that this method might be used to facilitate gene incorporation into the hepatocyte DNA under experimental conditions. Because partial hepatectomy has been most commonly used in intact 


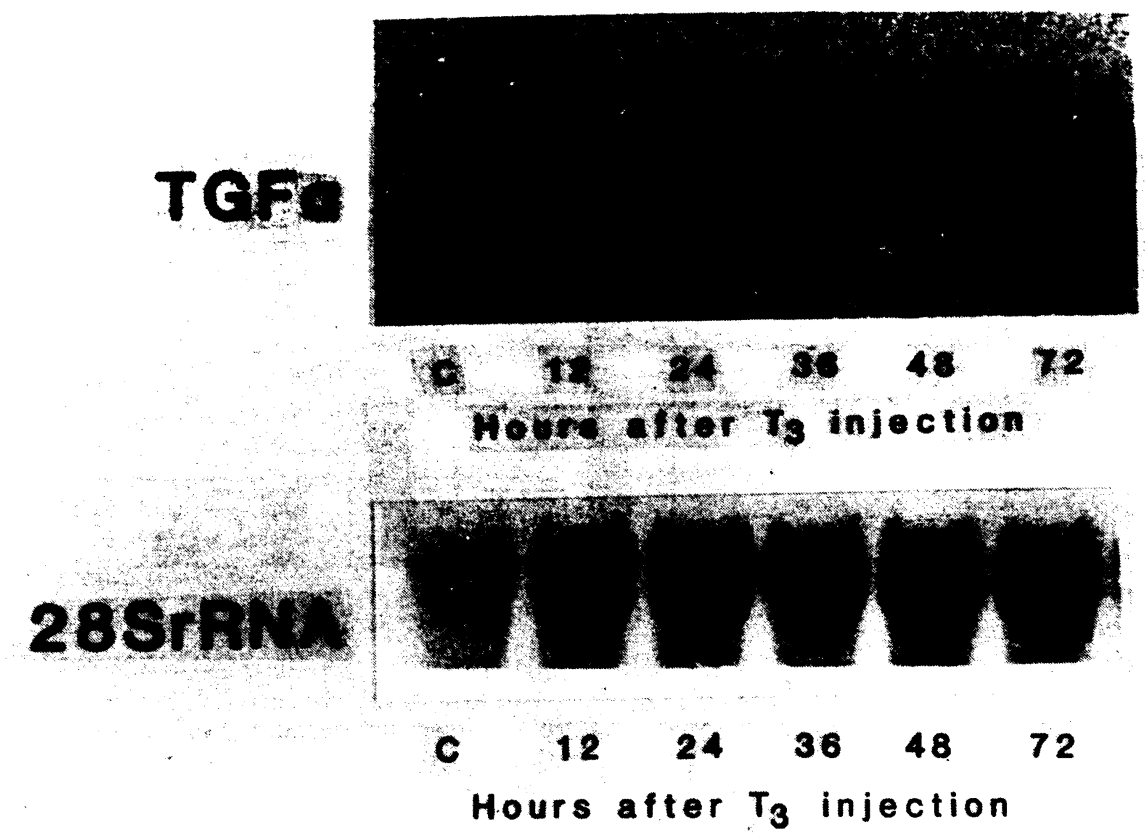

FIG. 3. Northern-blot analysis of TGF- $\alpha$ mRNA from livers of resting rats and from livers of rats at different points after a single injection of $\mathrm{T}_{3}(200 \mu \mathrm{g} / 100 \mathrm{gm}$ body wt).

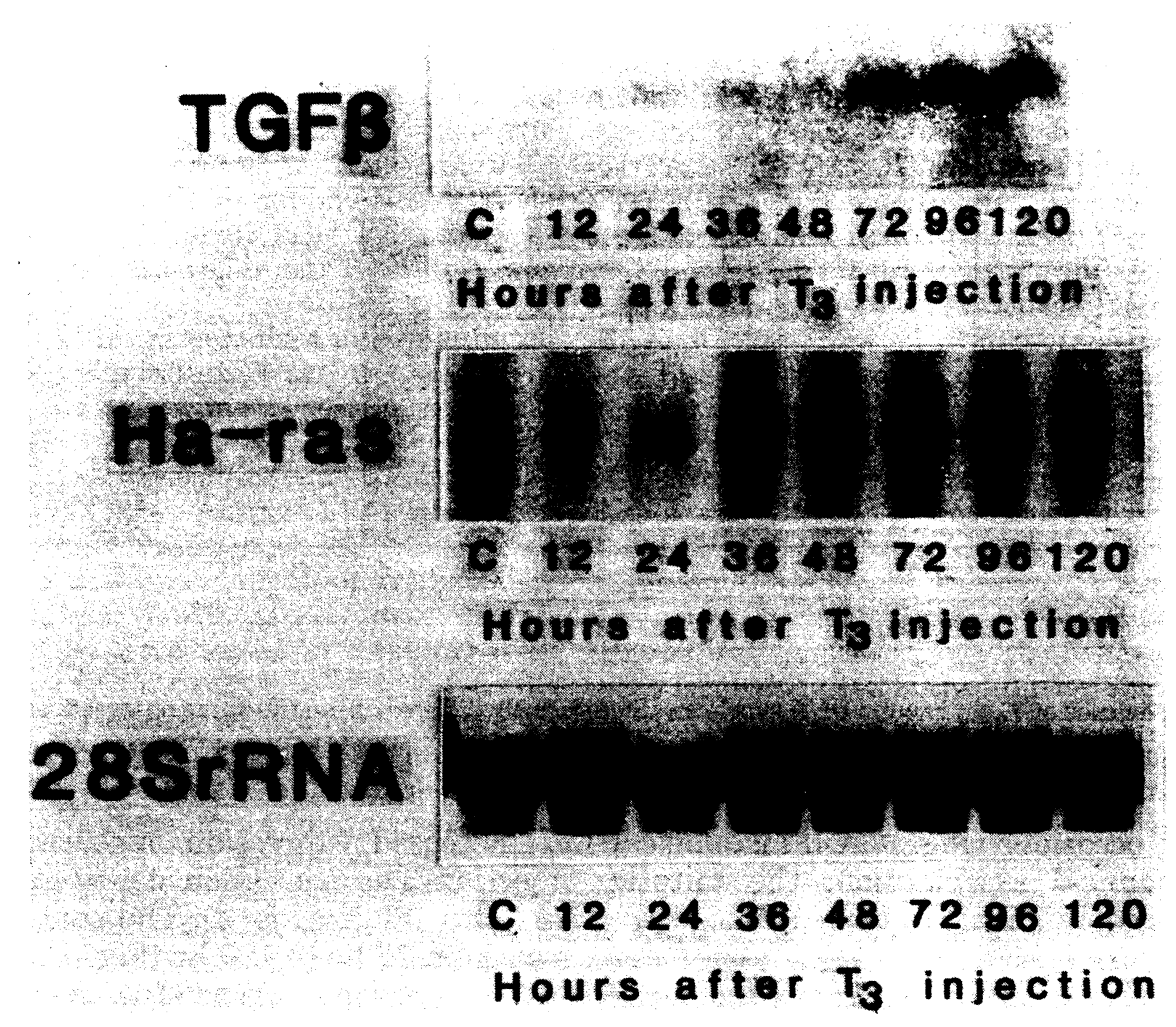

FIG. 4. Northern-blot analysis of TGF- $\beta 1$ and c-Ha-ras mRNA levels from livers of resting rats and from livers of rats at different times after a single injection of $\mathrm{T}_{3}(200 \mu \mathrm{g} / 100 \mathrm{gm}$ body wt).

animals to provide the hyperplasia necessary for efficient and prolonged gene transfection (8, 21-23), comparisons of the two techniques are in order.

In most respects, the response to the $\mathrm{T}_{3}$ doses used was similar to that following a moderate hepatic resection, with a peak response at $24 \mathrm{hr}$ and return to baseline by 4 days. The secondary peak of DNA synthesis, at $48 \mathrm{hr}$, was not attributable to delayed ab- 
sorption of the subcutaneously injected $\mathrm{T}_{3}$, in view of the $\mathrm{T}_{3}$ serum levels, which were maximal at day 1 and back to baseline by day 4 in association with proliferation of nonparenchymal cells, which are well known to have a delayed time of proliferation (24). A secondary small burst of DNA synthesis also has been seen after partial hepatectomy (25) and may represent in part a temporarily dissociated bile duct cell response (26-27). However, it was clear from the histopathological studies that the principal proliferation after $\mathrm{T}_{3}$ was that of hepatocytes. Of considerable practical importance in the gene therapy context was the induction of undiminished proliferative response at 10-day intervals.

The changes in liver mRNA of hepatic growthassociated genes also were identical after $T_{3}$ injection to those known to occur after partial hepatectomy, including the expression of TGF- $\alpha$ at $24 \mathrm{hr}, \mathrm{TGF}-\beta$ at 72 to $120 \mathrm{hr}$ and c-Ha-ras from 24 to $120 \mathrm{hr}$. Minor deviations from the orderly sequence after partial hepatectomy included a delayed secondary peak of TGF- $\alpha$ mRNA at $72 \mathrm{hr}$ and more prolonged expression of c-Ha-ras.

These experiments support the feasibility of using a pharmacological approach as an alternative to hepatic resection for creation of a hyperplastic microenvironment conducive to gene insertion. For this purpose, $\mathrm{T}_{3}$ is only one of several candidates-including hormones, growth factors and some of the most potent T-cell-directed immunosuppressive agents (4). The need to screen for such substances for their hepatic growth effect in intact animals as opposed to tissue culture conditions was emphasized before (4) and exemplified in the in vitro experiments of this report, in which $\mathrm{T}_{3}$ alone was almost inert. The dose-related effect of $T_{3}$ was detected in tissue culture only when it was added to a medium enriched with EGF. This finding is a simple demonstration of the complexity of the process of liver regeneration in vivo, which is a multifactorial phenomenon that includes several growth factors, hormones and cellular matrix components, along with complicated cell-to-cell interactions.

\section{REFERENCES}

1. Canzanelli $A D$, Rapport $D$, Guild $R$. Control of liver regeneration and nucleic acid content by the thyroid: with observations on the effects of pyrimidines. Am J Physiol 1949;157:225-229.

2. Short J, Brown RF, Husakova A, Gilbertson JR, Zemel R, Lieberman I. Induction of deoxyribonucleic acid synthesis in the liver of the intact animal. J Biol Chem 1972;247:1757-1766.

3. Francavilla A, Ove P, Van Thiel DH, Coetzee ML, Wu SK, DiLeo $A$, Starzl TE. Induction of hepatocyte stimulating activity of $T_{3}$ and appearance of the activity despite inhibition of DNA synthesis by adriamycin. Horm Metab Res 1984;16:237-242.

4. Francavilla A, Starzl TE, Porter K, Foglieni CS, Michalopoulous GK, Carrieri G, Trejo J, et al. Screening for candidate hepatic growth factors by selective portal infusion after canine Eck fistula. HEPATOLOGY 1991;14:665-670.

5. Starzl TE, Watanabe K, Porter KA, Putnam CW. Effects of insulin, glucagon, and insulin/glucagon infusions on liver morphology and cell division after complete portacaval shunt in dogs. Lancet 1976;1:821-825.
6. Bucher NLR, Swaffield MN. The rate of incorporation of labeled thymidine into deoxyribonucleic acid of regenerating rat liver in relation to the amount of liver excised. Cancer Res 1964;24:16111625.

7. Fausto N, Mead JE. Regulation of liver growth: protooncogenes and transforming growth factors. Lab Invest 1989;60:4-13.

8. Wu GY, Wilson JM, Shalaby F, Grossman M, Shafritz DA, Wu CH Receptor-mediated gene delivery in vivo: partial correction of genetic analbuminemia in Nagase rats. J Biol Chem 1991;266: 14338-14342.

9. Derynck R, Jarret JA, Chen EY, Eaton DH, Bell JR, Assoian RK Roberts $A B$, et al. Human transforming growth factors-beta complementary DNA sequence and expression in normal and transformed cells. Nature 1985;316:701-705.

10. Lee DC, Rose TM, Webb NR, Todaro GJ. Cloning and sequence analysis of a cDNA for rat transforming growth factors alpha. Nature 1985;313:489-491.

11. Francavilla A, Eagon PK, Di Leo A, Polimeno L. Sex hormone related functions in regenerating male rat liver. Gastroenterology 1986;91:1262-1270.

12. Francavilla A, Barone M, Starzl TE, Zeevi A, Scotti C, Carrieri G, Mazzaferro V, et al. FK 506 as a growth control factor. Transplant Proc 1990;23:90-92.

13. Lowry OH, Rosebrough NJ, Farr AL, Randall RJ. Protein measurement with the Folin phenol reagent. J Biol Chem 1951;193: 265-275.

14. Palmer PE, Safall H, Wolfe HJ. Alpha-1 antitrypsin and alphafetoprotein: protein markers in endodermal sinus (yolk sac) tumors. Am J Clin Pathol 1976;65:575-582.

15. Strenberger LA. Immunocytochemistry. 2nd ed. New York: John Wiley \& Sons, 1979.

16. Francavilla A, Ove P, Polimeno L, Sciascia C, Coetzee ML, Starzl TE. Epidermal growth factor and proliferation in rat hepatocytes in primary cultures isolated at different times after partial hepatectomy. Cancer Res 1986;46:1318-23.

17. Seglen PO. Preparation of isolated rat liver cell. Methods Cell Biol 1976;13:29-83.

18. Jirtle RL, Michalopoulos G, McLaine JR, Crowley J. Transplantation system for determining the clonogenic survival of parenchymal hepatocytes exposed to ionizing radiation. Cancer Res 1981;41:3512-3518.

19. Setaro F, Morley CGD. A modified fluorimetric method for the determination of microgram quantities of DNA from cell tissue cultures. Anal Biochem 1976;71:313-317.

20. Carr BI, Huang TH, Itakura K, Neel M, Marceau N. TGFB gene transcription in normal and neoplastic liver growth. J Cell Biochem 1989;39:477-487.

21. Varmus HE, Padgett T, Heasley S, Simon G, Bishop JM. Cellular functions are required for the synthesis and integration of avian sarcoma virus-specific DNA. Cell 1977;11:307-319.

22. Wu GY, Wu CH. Receptor-mediated gene delivery and expression in vivo. J Biol Chem 1988;263:14621-14624.

23. Wu CH, Wilson JM, Wu GY. Targeting genes: delivery and persistent expression of a foreign gene driven by mammalian regulatory elements in vivo. J Biol Chem 1989;264:1698516987.

24. Widmann JJ, Fahimi D. Proliferation of mononuclear phagocytes (Kuppfer Cells) and endothelial cells in regeneration rat liver. Am J Pathol 1975;80:349-360.

25. Bucher NRL, Malt RA. Regeneration of liver and kidney. Boston: Little, Brown \& Co., 1971:1-176.

26. Grisham JW. Morphologic study of deoxyribonucleic acid synthesis and cell proliferation in regenerating rat liver: autoradiography with 3H-thymidine. Cancer Res 1962;22: 842-847.

27. Polimeno L, Azzarone A, Zeng QH, Panella C, Subbotin W, Carr B, Bouzahzah B, et al. Cell proliferation and oncogene expression after bile duct ligation in the rat: evidence of a specific growth effect on bile duct cells. HEPATOLOGY, in press. 